\title{
PHYSIOLOGICAL AND BIOCHEMICAL RESPONSES OF SUGARCANE VARIETIES TO SALT STRESS ${ }^{1}$
}

\author{
WELSON LIMA SIMÕES ${ }^{2 *}$, DANIELA SIQUEIRA COELHO ${ }^{3}$, ALESSANDRO CARLOS MESQUITA ${ }^{4}$, MARCELO \\ CALGARO $^{2}$, JUCICLÉIA SOARES DA SILVA ${ }^{2}$
}

\begin{abstract}
Salt stress is one of the most limiting environmental factors for agricultural yields in the Semiarid region of Brazil. Considering the expansion of areas with sugarcane crops in this region, the selection of more adapted plant varieties to this environment is an essential tool for the sustainability of this activity. Thus, the objective of the present work was to evaluate the physiological and biochemical responses of plants of ten sugarcane varieties to salt stress. The experiment was conducted in a greenhouse using a randomized block design, in a $6 \times 10$ factorial arrangement consisting of six salinity levels in the irrigation water $(0,1.0,2.0$, 4.0, 6.0, and 8.0 dS m ${ }^{-1}$ ) and ten sugarcane varieties (VAT 90212, RB 72454, RB 867515, Q 124, RB 961003, RB 957508, SP 791011, RB 835089, RB 92579, and SP 943206), with three replications. Salt waters were applied every two days to increase the soil moisture to field capacity and promote leaching. The gas exchange, chlorophyll content, and total soluble and reducing sugars of leaves were evaluated at 90 days after planting. The highest chlorophyll contents were found in plants of the varieties Q 124, RB 96103, RB 835089, and SP 943206. The effect of salinity on the sugarcane plants affected their leaf gas exchanges and total soluble and reducing sugar contents, denoting the adaptability of plants to the stress conditions evaluated. The decrease of stomatal conductance resulted in decreases in photosynthetic rates in plants of all sugarcane varieties evaluated, except for RB 867515.
\end{abstract}

Keywords: Gas Exchange. Saccharum officinarum. Carbohydrates. Salinity.

\section{ASPECTOS FISIOLÓGICOS E BIOQUÍMICOS EM VARIEDADES DE CANA-DE-AÇÚCAR SUBMETIDAS A ESTRESSE SALINO}

\begin{abstract}
RESUMO - O estresse salino é um dos fatores ambientais que mais limitam a produtividade agrícola no semiárido brasileiro. Considerando-se a expansão da área de cultivo de cana-de-açúcar nesta região, a seleção de variedades cada vez mais adaptadas a este meio ambiente torna-se uma ferramenta fundamental para sua sustentabilidade. Assim, o presente trabalho teve como objetivo avaliar as respostas fisiológicas e bioquímicas de dez variedades de cana-de-açúcar submetidas à salinidade. $\mathrm{O}$ experimento foi conduzido em casa de vegetação no delineamento de blocos casualizados, em esquema fatorial $6 \times 10$, com seis níveis de salinidade da água de irrigação $\left(0 ; 1,0 ; 2,0 ; 4,0 ; 6,0\right.$ e $\left.8,0 \mathrm{dS} \mathrm{m}^{-1}\right)$ e dez variedades de cana-de-açúcar (VAT 90212, RB 72454, RB 867515, Q 124, RB 961003, RB 957508, SP 791011, RB 835089, RB 92579 e SP 943206), com três repetições. As águas salinas foram aplicadas a cada dois dias a fim de elevar a umidade do solo à capacidade de campo e promover lixiviação. Aos 90 dias após o plantio foram avaliadas as trocas gasosas, o teor de clorofila e os açucares solúveis totais e redutores das folhas. Os maiores teores de clorofila foram obtidos nas variedades Q 124, RB 96103, RB 835089 e SP 943206. O efeito da salinidade sobre as variedades de cana-de-açúcar influenciou na variação das trocas gasosas, no teor de açúcares solúveis totais e açúcares redutores, demonstrando uma adaptabilidade da planta às condições de estresse submetida. A redução da condutância estomática resultou na diminuição das taxas fotossintéticas de todas as variedades de cana-deaçúcar avaliadas, exceto a RB 867515.
\end{abstract}

Palavras-chave: Trocas gasosas. Saccharum officinarum. Carboidratos. Salinidade.

\footnotetext{
${ }^{*}$ Corresponding author

${ }^{1}$ Received for publication in 05/13/2019; accepted in 10/08/2019.

Paper extracted from the Embrapa Semiarid Research Project.

${ }^{2}$ Embrapa Semiárido, Empresa Brasileira de Pesquisa Agropecuária, Petrolina, PE, Brazil; welson.simoes@embrapa.br - ORCID: 00000003-1474-9410, marcelo.calgaro@embrapa.br - ORCID: 0000-0002-4995-5946, jucicleiass@gmail.com - ORCID: 0000-0003-34090326.

${ }^{3}$ Instituto do Meio Ambiente e Recursos Hídricos, Juazeiro, BA, Brazil; daniela.coelho@hotmail.com, ORCID: 0000-0003-1125-6960.

${ }^{4}$ Department of Technology and Social Sciences, Campus III, Universidade do Estado da Bahia, Juazeiro, BA, Brazil, amesquita@uneb.br, ORCID: 0000-0002-9754-1676.
} 


\section{INTRODUCTION}

The Northeast region of Brazil presents a great potential for sugarcane production and consequently, ethanol; however, some factors, such as the low volume and irregular distribution of rainfalls and the inadequate topography for mechanization in several areas, limit the sugarcane production in this region (BARROS et al., 2018; LEAL et al., 2017).

However, the development of irrigated agriculture, mainly in the São Francisco River Valley, enabled the growing of sugarcane crops with yields above the national mean, reaching $71.3 \mathrm{Mg}$ ha ${ }^{-1}$ in the 2018/2019 crop season (CONAB, 2019). The advantages of irrigated over rainfed sugarcane crops are related to the higher growth, culm density, leaf area index, and sugar content when compared to rainfed crops (SIMÕES et al., 2015; SIMÕES et al., 2018).

The main problem caused by high soil salinity is the decrease of osmotic potential of the soil solution, which decreases water availability and increases toxicity of sodium and chloride to plants (DIAS; BLANCO, 2010; TAIZ et al., 2017).

The effects of high salinity on plants is very complex; it involves changes on plant morphology, growth, and physiological and biochemical processes, which can be caused by difficulties in water absorption, and toxicity of specific ions, decreasing plant growth, development, quality, and yield or causing the total loss of its production. The growth processes are particularly sensitive to effects of high salinity; thus, growth rate and photosynthetic capacity are good parameters to evaluate these effects and the plant's capacity to tolerate this stress (CORREIA et al., 2009; DIAS; BLANCO, 2010). The photosynthesis process and cell growth in plants under salt stress are affected due to decreases in carbon dioxide availability (SIMÕES et al., 2018).

Total free amino acids and total soluble sugars represent quantitatively the most important organic solutes for osmotic control and for protection of cell structures (SIMÕES et al., 2015).

Therefore, evaluating mechanisms developed by plants to thrive under salt stress is important to identify more tolerant genotypes. In this context, the objective of the present work was to evaluate physiological and biochemical responses of ten sugarcane varieties subjected to different salinity levels.

\section{MATERIAL AND METHODS}

The experiment was conducted in a greenhouse at the Brazilian Agricultural Research Corporation (Embrapa Semiarid), in Petrolina, PE, Brazil $\left(9^{\circ} 09^{\prime} \mathrm{S}, 40^{\circ} 22^{\prime} \mathrm{W}\right.$, and altitude of $\left.365.5 \mathrm{~m}\right)$.

The climate of the region is BSWh, tropical semiarid, according to the Köppen classification; the rainfall is concentrated between November and April, with mean annual depth of $540 \mathrm{~mm}$, irregularly distributed. The region presents mean annual air temperature of $26.5^{\circ} \mathrm{C}$, varying from 21 to $32{ }^{\circ} \mathrm{C}$, mean annual evaporation of $2000 \mathrm{~mm}$, mean annual air relative humidity of $67.8 \%$, with 3.000 hours of sunshine, and mean wind speed of $2.3 \mathrm{~m} \mathrm{~s}^{-1}$ (REDDY; AMORIM NETO, 1983).

A randomized block experimental design was used, in a $6 \times 10$ factorial arrangement consisted of six salinity levels in the irrigation water $(0,1.0,2.0$, $4.0,6.0$, and $\left.8.0 \mathrm{dS} \mathrm{m}^{-1}\right)$ and ten sugarcane varieties (VAT 90212, RB 72454, RB 867515, Q 124, RB 961003, RB 957508, SP 791011, RB 835089, RB 92579, and SP 943206), with three replications.

The experiment was conducted using $10-\mathrm{dm}^{3}$ polyethylene pots with a local soil (Typic Quartzipsamment), whose chemical and texture characteristics were analyzed according to the methodology described by EMBRAPA (2017) and presented in Table 1.

The soil acidity was corrected by applying dolomitic lime at 90 days before planting and the soil fertility was corrected by applying macro and micronutrients, based on the results of the soil analysis.

Two sugarcane setts were planted in each pot; the setts were from a crop area of a private company (Agroindustria do Vale of São Francisco S/A Agrovale). The solo of the pots was irrigated up to field capacity, using public water.

Table 1. Chemical and physical characteristics of the soil used to evaluate sugarcane plants of different varieties subjected to different salinity levels.

\begin{tabular}{|c|c|c|c|c|c|c|c|c|}
\hline $\begin{array}{c}\text { Organic matter } \\
\mathrm{g} \mathrm{kg}^{-1}\end{array}$ & $\begin{array}{c}\mathrm{pH} \mathrm{H}_{2} \mathrm{O} \\
(1: 2,5)\end{array}$ & $\begin{array}{c}\mathrm{EC}_{\mathrm{se}} \\
\mathrm{dS} \mathrm{m}^{-1}\end{array}$ & $\mathrm{Ca}^{2+}$ & $\mathrm{Mg}^{2+}$ & $\mathrm{Na}^{+}$ & $\mathrm{K}^{+}$ & $\mathrm{Al}^{3+}$ & $\overline{\mathrm{CEC}}$ \\
\hline 10.2 & 4.8 & 0.6 & 1.4 & 0.4 & 0.04 & 0.28 & 0.05 & 3.6 \\
\hline $\begin{array}{c}\mathrm{P} \\
\mathrm{mg} \mathrm{dm^{-3 }}\end{array}$ & $\begin{array}{l}\mathrm{V} \\
\%\end{array}$ & $\mathrm{Cu}$ & $\mathrm{Fe}$ & $\mathrm{Mn}$ & $\mathrm{Zn}$ & Sand & $\begin{array}{c}\text { Silt } \\
--\%--\end{array}$ & Clay \\
\hline 4.2 & 59 & 0.2 & 9.1 & 12.0 & 1.1 & 73.0 & 19.0 & 8.0 \\
\hline
\end{tabular}

$\mathrm{EC}_{\mathrm{se}}=$ electrical conductivity of the saturation extract; $\mathrm{Ca}^{2+}=$ exchangeable calcium; $\mathrm{Mg}^{2+}=$ exchangeable magnesium; $\mathrm{Na}^{+}=$exchangeable sodium; $\mathrm{K}^{+}=$exchangeable potassium; $\mathrm{Al}^{+3}$ : exchangeable acidity; $\mathrm{CEC}=$ cation exchange capacity at $\mathrm{pH}$ 7.0; $\mathrm{P}=$ available phosphorus $\left(\mathrm{Mehlich}^{-1}\right)$; $\mathrm{BS}=$ base saturation; $\mathrm{Fe}=$ available iron; $\mathrm{Mn}=$ available manganese; $\mathrm{Cu}=$ available copper; $\mathrm{Zn}=$ available zinc. Micronutrients extracted by $\mathrm{Mehlich}^{-1}$. 
The salt waters used in the irrigations were artificially salinized with sodium chloride $(\mathrm{NaCl})$, calcium chloride $\left(\mathrm{CaCl}_{2} \cdot 2 \mathrm{H}_{2} \mathrm{O}\right)$, and magnesium sulfate $\left(\mathrm{MgSO}_{4} .7 \mathrm{H}_{2} \mathrm{O}\right)$ at the proportion of $7: 2: 1$ (Na:Ca:Mg). The salt waters were replaced weekly and the water removed was stored in a shaded location to avoid changes in its properties by evaporation and variation in temperature. The salt waters were applied every two days up to a leaching fraction of $15 \%$ to maintain the soil salinity level at similar levels to the irrigation water.

The leaves of the plants were evaluated for gas exchange after 90 days of salt stress, using a portable infrared gas analyzer (IRGA; Li-6400, Licor $^{\circledR}$, Lincoln, USA) with an artificial light fixed at $2,000 \mu \mathrm{mol} \mathrm{m} \mathrm{m}^{-2} \mathrm{~s}^{-1}$. The plant physiological variables analyzed were: net photosynthetic rate $(A)$, stomatal conductance $(g s)$, and transpiration $(E)$. The total chlorophyll content was determined by readings on three points of the +3 leaves, using a chlorophyll meter (ClorofiLOG-CFL1030; Falker, Porto Alegre, Brazil).

Sugar extractions were done by macerating fresh leaves with a phosphate buffer $(1.0 \mathrm{M})$ set to $\mathrm{pH}$ 7.0. The material was, then, centrifuged at 2,000 $\mathrm{g}$, and the supernatant was collected for analysis.

Total soluble sugars (TSS) were determined according to the antrona method, and total reducing sugars (TRS) were determined by using 3,5dinitrosalicylic acid. The standard curves were adjusted using glucose solutions, with subsequent readings in a UV spectrophotometer at wavelengths of 620 and $540 \eta \mathrm{m}$ for TSS and TRS, respectively.

The data obtained were subjected to analysis of variance, using the Sisvar 5.0 program. In cases that presented significant interaction between sugarcane varieties and salinity levels, the variables were analyzed within each factor; otherwise, the effect of the factors was considered independent for the variables evaluated.

The salinity levels were compared by firstand second-degree regression models when significant at $5 \%$ probability. The varieties were compared by the mean test of Scott Knott at 5\% probability.

\section{RESULTS AND DISCUSSION}

According to the gas exchange and biochemical evaluations, the interaction between sugarcane varieties and electrical conductivities of the irrigation water $\left(\mathrm{EC}_{\mathrm{W}}\right)$ was not significant only for the chlorophyll content (Table 2). The chlorophyll content was affected by the salinity levels and by the varieties.

Table 2. Gas exchange and biochemical attributes in sugarcane varieties subjected to different salinity levels.

\begin{tabular}{ccccccc}
\hline & \multicolumn{5}{c}{ Mean square } \\
\cline { 2 - 7 } & $A$ & $g s$ & $E$ & Chlorophyll & TSS & TRS \\
\hline Variety & $307.7^{* *}$ & $0.028^{* *}$ & $15.3^{* *}$ & $123.7^{* *}$ & $20.115^{* *}$ & $21.459^{* *}$ \\
EC $_{\mathrm{W}}$ & $1.383^{* *}$ & $0.111^{* *}$ & $58.8^{* *}$ & $485.7^{* *}$ & $40.711^{* *}$ & $6.476^{* *}$ \\
Variety $\times \mathrm{EC}_{\mathrm{W}}$ & $74.1^{*}$ & $0.006^{*}$ & $3.17^{*}$ & $57.7^{\text {ns }}$ & $21.239^{* *}$ & $11.394^{* *}$ \\
Residue & 45.9 & 0.004 & 2.12 & 43.6 & 4.650 & 826 \\
\hline CV (\%) & 29.0 & 35.0 & 29.6 & 24 & 18 & 14 \\
\hline
\end{tabular}

$A=$ net photosynthetic rate; $g S=$ stomatal conductance; $E=$ transpiration; TSS $=$ total soluble sugars; TRS $=$ total reducing sugars; $\mathrm{EC}_{\mathrm{W}}=$ electrical conductivity of the irrigation water; $\mathrm{CV}=$ coefficient of variation; $*, * *$, and ${ }^{\mathrm{ns}}=$ significant at $5 \%$, $1 \%$, and not significant, respectively.

The highest chlorophyll contents were found in plants of the varieties Q 124, RB 961003, RB 835089, and SP 943206 (Figure 1A). Chlorophyll is important for the photosynthesis process because it is responsible to capture light energy for photochemical reactions (TAIZ et al., 2017); thus, high chlorophyll contents favor gas exchange and can contribute to the adaptation of plants to salt stress conditions. Among these sugarcane varieties with the highest chlorophyll contents, RB 835089 has presented the highest number of leaves, stem diameter, and plant weight when subjected to salinity (SIMÕES et al.,
2016). This denotes the importance of chlorophyll for photosynthesis and, consequently, for photoassimilates accumulation and plant growth. Willadino et al. (2011) evaluated plants of the sugarcane variety RB 867515 and found that the decrease in chlorophyll content was a protection mechanism of the plant; the plant reduces the light energy caption and, consequently, the electron flux in the electron transport chain, and reduces $\mathrm{CO}_{2}$ assimilation, which partially decreases oxygen, forming reactive oxygen species (BROSCHÉ et al., 2010). 
A

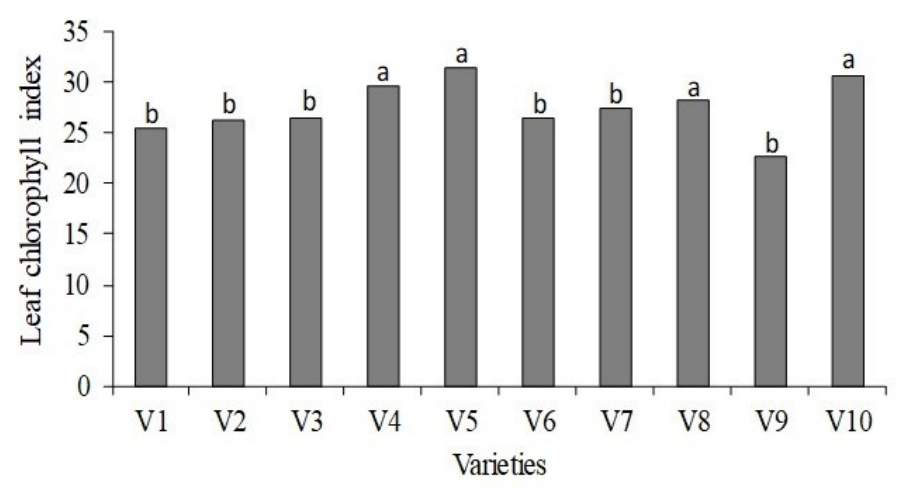

$\mathrm{B}$

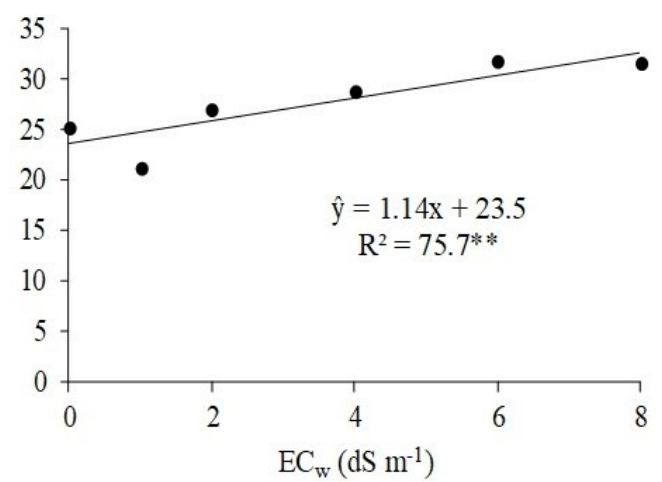

Figure 1. Leaf chlorophyll index of sugarcane plants of different varieties [VAT 90212 (V1), RB 72454 (V2), RB 867515 (V3), Q 124 (V4), RB 961003 (V5), RB 957508 (V6), SP 791011 (V7), RB 835089 (V8), RB 92579 (V9) e SP 943206 (V10)] (A) in response to different salinity levels (B). Columns with the same letter are not different by the Scott Knott test at $5 \%$ probability. $* *$ significant regression at $5 \%$ probability.

The chlorophyll index increased linearly as the electrical conductivity of the irrigation water was increased, regardless of the sugarcane varieties evaluated (Figure 1B), representing less susceptibility to salt stress, since decreases in chlorophyll contents are common in sensitive plants to high salinity (JAMIL et al., 2007). Considering the lack of interaction between the sugarcane varieties and salinity levels evaluated, little difference in tolerance level was found between the varieties for this variable.

The effect of salinity on the sugarcane plants affected their gas exchange (Tables 3,4 and 5) and total soluble and reducing sugar contents (Tables 6 and 7).

The stomatal conductance $(g s)$ decreased, resulting in decreases in photosynthetic rates $(A)$ in all sugarcane varieties evaluated, except for $\mathrm{RB}$ 867515 (Table 3), which may represent a greater adaptation of plants of this variety to salt stress.

Table 3. Photosynthetic rate $(A)\left(\mu \mathrm{mol} \mathrm{CO}_{2} \mathrm{~m}^{-2} \mathrm{~s}^{-1}\right)$ in sugarcane plants of different varieties subjected to different salinity levels.

\begin{tabular}{|c|c|c|c|c|c|c|c|c|}
\hline \multirow[b]{2}{*}{ Variety } & \multicolumn{6}{|c|}{$\mathrm{EC}_{\mathrm{W}}\left(\mathrm{dS} \mathrm{m} \mathrm{m}^{-1}\right)$} & \multirow{2}{*}{$\begin{array}{c}\text { Regression } \\
\text { equation }\end{array}$} & \multirow{2}{*}{$\mathrm{R}^{2}$} \\
\hline & 0.0 & 1.0 & 2.0 & 4.0 & 6.0 & 8.0 & & \\
\hline VAT 90212 & $37.1 \mathrm{a}$ & $23.6 \mathrm{~b}$ & $18.4 \mathrm{~b}$ & $11.0 \mathrm{a}$ & $13.6 \mathrm{~b}$ & $9.8 \mathrm{~b}$ & $\hat{y}=0.70 x^{2}-8.3 x+34$ & $91.4^{* *}$ \\
\hline RB 72454 & $40.9 \mathrm{a}$ & $32.8 \mathrm{a}$ & $18.3 \mathrm{~b}$ & $25.6 \mathrm{a}$ & $24.6 \mathrm{a}$ & $26.8 \mathrm{a}$ & $\hat{y}=0.74 x^{2}-7.1 x+38$ & $64.0 * *$ \\
\hline RB 867515 & $28.3 \mathrm{~b}$ & $23.0 \mathrm{~b}$ & $13.7 \mathrm{~b}$ & $22.9 \mathrm{a}$ & $23.8 \mathrm{a}$ & $18.6 \mathrm{a}$ & $\hat{y}=\bar{y}$ & -- \\
\hline Q 124 & $22.2 \mathrm{~b}$ & $32.1 \mathrm{a}$ & $22.7 \mathrm{~b}$ & $16.9 \mathrm{a}$ & $19.0 \mathrm{a}$ & $10.0 \mathrm{~b}$ & $\hat{y}=-1.9 x+27$ & $64.9^{* *}$ \\
\hline RB 961003 & $42.5 \mathrm{a}$ & $28.2 \mathrm{a}$ & $34.5 \mathrm{a}$ & $19.6 \mathrm{a}$ & $19.6 \mathrm{a}$ & $20.5 \mathrm{a}$ & $\hat{y}=0.56 x^{2}-7.0 x+41$ & $83.2^{*}$ \\
\hline RB 957508 & $30.7 \mathrm{~b}$ & $22.1 \mathrm{~b}$ & $15.8 \mathrm{~b}$ & $19.7 \mathrm{a}$ & $21.4 \mathrm{a}$ & $11.8 \mathrm{~b}$ & $\hat{y}=-1.5 x+25$ & $50.4^{*}$ \\
\hline SP 791011 & $30.7 \mathrm{~b}$ & $20.0 \mathrm{~b}$ & $26.7 \mathrm{a}$ & $15.6 \mathrm{a}$ & $9.4 \mathrm{~b}$ & $14.5 \mathrm{~b}$ & $\hat{y}=-2.1 x+27$ & $67.1^{* *}$ \\
\hline RB 835089 & $46.9 \mathrm{a}$ & $32.5 \mathrm{a}$ & $27.6 \mathrm{a}$ & $23.4 \mathrm{a}$ & $27.6 \mathrm{a}$ & $24.7 \mathrm{a}$ & $\hat{y}=0.72 x^{2}-7.7 x+43$ & $81.9^{* *}$ \\
\hline RB 92579 & $42.5 \mathrm{a}$ & $28.0 \mathrm{a}$ & $23.3 \mathrm{~b}$ & $28.4 \mathrm{a}$ & $16.5 \mathrm{~b}$ & $13.6 \mathrm{~b}$ & $\hat{y}=-2.9 x+35$ & $74.7^{* *}$ \\
\hline SP 943206 & $28.3 \mathrm{~b}$ & $33.5 \mathrm{a}$ & $19.9 \mathrm{~b}$ & $15.8 \mathrm{a}$ & $12.5 \mathrm{~b}$ & $18.2 \mathrm{a}$ & $\hat{y}=0.55 x^{2}-6.3 x+32$ & $77.0^{*}$ \\
\hline
\end{tabular}

Means followed by the same letter in the column are not different by the Scott Knott test at $5 \%$ probability. $*$ and $* *=$ significant regression at $5 \%$ and $1 \%$ probability, respectively. 
W. L. SIMÕES et al.

Table 4. Stomatal conductance $(g s)\left(\mathrm{mol} \mathrm{m}^{-2} \mathrm{~s}^{-1}\right)$ in sugarcane plants of different varieties subjected to different salinity levels.

\begin{tabular}{|c|c|c|c|c|c|c|c|c|}
\hline \multirow[b]{2}{*}{ Variety } & \multicolumn{6}{|c|}{$\mathrm{EC}_{\mathrm{W}}\left(\mathrm{dS} \mathrm{m}^{-1}\right)$} & \multirow{2}{*}{$\begin{array}{c}\text { Regression } \\
\text { equation }\end{array}$} & \multirow{2}{*}{$\mathrm{R}^{2}$} \\
\hline & 0.0 & 1.0 & 2.0 & 4.0 & 6.0 & 8.0 & & \\
\hline VAT 90212 & $0.31 \mathrm{~b}$ & $0.16 \mathrm{a}$ & $0.12 \mathrm{a}$ & $0.07 \mathrm{~b}$ & $0.10 \mathrm{~b}$ & $0.13 \mathrm{a}$ & $\hat{y}=0.01 x^{2}-0.09 x+0.28$ & $90.6^{* *}$ \\
\hline RB 72454 & $0.37 \mathrm{a}$ & $0.28 \mathrm{a}$ & $0.16 \mathrm{a}$ & $0.19 \mathrm{a}$ & $0.21 \mathrm{a}$ & $0.21 \mathrm{a}$ & $\hat{y}=0.01 x^{2}-0.07 x+0.34$ & $73.6^{* *}$ \\
\hline RB 867515 & $0.32 \mathrm{~b}$ & $0.17 \mathrm{a}$ & $0.12 \mathrm{a}$ & $0.20 \mathrm{a}$ & $0.19 \mathrm{a}$ & $0.16 \mathrm{a}$ & $\hat{y}=-0.01 x+0.22$ & $17.9^{*}$ \\
\hline Q 124 & $0.14 \mathrm{c}$ & $0.22 \mathrm{a}$ & $0.17 \mathrm{a}$ & $0.10 \mathrm{~b}$ & $0.17 \mathrm{a}$ & $0.07 \mathrm{a}$ & $\hat{y}=\bar{y}$ & -- \\
\hline RB 961003 & $0.40 \mathrm{a}$ & $0.23 \mathrm{a}$ & $0.26 \mathrm{a}$ & $0.17 \mathrm{a}$ & $0.16 \mathrm{a}$ & $0.17 \mathrm{a}$ & $\hat{y}=0.01 x^{2}-0.07 x+0.36$ & $83.5^{* *}$ \\
\hline RB 957508 & $0.21 \mathrm{c}$ & $0.14 \mathrm{a}$ & $0.10 \mathrm{a}$ & $0.12 \mathrm{~b}$ & $0.14 \mathrm{a}$ & $0.10 \mathrm{a}$ & $\hat{y}=\bar{y}$ & -- \\
\hline SP 791011 & $0.24 \mathrm{c}$ & $0.19 \mathrm{a}$ & $0.18 \mathrm{a}$ & $0.14 \mathrm{~b}$ & $0.06 \mathrm{~b}$ & $0.09 \mathrm{a}$ & $\hat{y}=-0.02 x+0.22$ & $87.2 * *$ \\
\hline RB 835089 & $0.29 \mathrm{~b}$ & $0.22 \mathrm{a}$ & $0.19 \mathrm{a}$ & $0.18 \mathrm{a}$ & $0.25 \mathrm{a}$ & $0.15 \mathrm{a}$ & $\hat{y}=\bar{y}$ & -- \\
\hline RB 92579 & $0.42 \mathrm{a}$ & $0.25 \mathrm{a}$ & $0.17 \mathrm{a}$ & $0.24 \mathrm{a}$ & $0.14 \mathrm{a}$ & $0.13 \mathrm{a}$ & $\hat{y}=0.01 x^{2}-0.07 x+0.35$ & $71.6^{*}$ \\
\hline SP 943206 & $0.26 \mathrm{c}$ & $0.27 \mathrm{a}$ & $0.14 \mathrm{a}$ & $0.11 \mathrm{~b}$ & $0.10 \mathrm{~b}$ & $0.14 \mathrm{a}$ & $\hat{y}=0.01 x^{2}-0.07 x+0.28$ & $84.4^{*}$ \\
\hline
\end{tabular}

Means followed by the same letter in the column are not different by the Scott Knott test at $5 \%$ probability. $*$ and $* *=$ significant regression at $5 \%$ and $1 \%$ probability, respectively.

Pacheco et al. (2013) evaluated sugarcane varieties and found that only the variety RB 867515 presented no significant decrease in net photosynthesis after 72 hours of salt stress, with mean value of 13.64, which was lower than those found in the present work for all salinity levels tested. Moreover, differences between photosynthetic rates as a function of the salinity levels applied were not found. In addition, among the varieties that presented significant decreases found by Pacheco et al. (2013), the highest percentage of decrease was found for the variety RB 92579 (89\%). This decrease was found for the same variety, however, with approximately $30 \%$ when compared to the control (PACHECO et al., 2013).

The salt stress altered the photosynthetic rate of the sugarcane varieties tested (Table 3 ). This may be connected to the alterations found for stomatal conductance (Table 4).

According to Pacheco et al. (2013), the variety RB 92579 presented significant lower gs $(37 \%)$ than the control, which decreased continuously after 72 hours $(88 \%)$, presenting the highest percentage of decrease in gs among the studied varieties. Table 4 shows that the decrease in gs was $30 \%$ for this same variety in the present study.

The increases in salinity levels generated stomatal closure, causing significant decreases in transpiration $(E)$ of plants of the varieties Q 124, SP 791011, and RB 835089 because of decreases in $g s$ (Table 4). This denotes a strategy of the plants to reduce water loss by transpiration, which is a mechanism of resistance to salt stress. However, considering the effect of salinity on the plants in each salinity level applied, the plants of the evaluated varieties subjected to $E_{\mathrm{IW}}$ of $8.0 \mathrm{dS} \mathrm{m}^{-1}$ showed no significant difference in transpiration rate $(E)$ (Table 5) and stomatal conductance $(g s)$ (Table 4). However, the varieties RB 72454, RB 867515, RB 961003, RB 835089, and SP 943206 presented higher photosynthetic rate (Table 3 ), indicating less sensitivity to salt stress than the other varieties.

The results showed that the salinity levels generated significant variation in transpiration in the plants of the sugarcane varieties evaluated (Table 5).

Pacheco et al. (2013) evaluated leaf transpiration in sugarcane plants subjected to salt stress and reported decreases of $38 \%$ and $29 \%$ in plants of varieties tolerant to drought (RB 92579 and RB 867515, respectively) after two hours of salt stress. However, leaf transpiration in the variety RB 92579 decreased after 72 hours $(76 \%)$. These results confirm those found in the present study for the variety RB 92579 (Table 5), which presented decreases in leaf transpiration; however, the variety RB 867515 presented no significant changes in leaf transpiration as a function of increasing electrical conductivity.

The increases in salinity levels resulted in decreases in $g s$, which characterizes the plant adaptability to salt stress conditions. According to Inman-Bamber and Smith (2005), decreases in $g s$ is an important strategy of sugarcane plants to avoid water losses through leaves.

Carbohydrate metabolism is also related to responses to abiotic stresses; some aspects of sugar metabolism regulation are mediate by droughts, by the abscisic acid, and by the sugar type. Regarding osmotic effects, salinity alters water absorption, ionic balance, and the permeability of cell membranes, which together change the plant metabolism, hormonal balance, gas exchange, and production in reactive oxygen species. 
W. L. SIMÕES et al.

Table 5. Transpiration $(E)\left(\mathrm{mol} \mathrm{H}_{2} \mathrm{O} \mathrm{m}^{-2} \mathrm{~s}^{-1}\right)$ in sugarcane plants of different varieties subjected to different salinity levels.

\begin{tabular}{|c|c|c|c|c|c|c|c|c|}
\hline \multirow{2}{*}{ Variety } & \multicolumn{6}{|c|}{$\mathrm{EC}_{\mathrm{W}}\left(\mathrm{dS} \mathrm{m}^{-1}\right)$} & \multirow{2}{*}{$\begin{array}{l}\text { Regression } \\
\text { equation }\end{array}$} & \multirow{2}{*}{$\mathrm{R}^{2}$} \\
\hline & 0.0 & 1.0 & 2.0 & 4.0 & 6.0 & 8.0 & & \\
\hline VAT 90212 & $8.2 \mathrm{a}$ & $4.5 \mathrm{a}$ & $3.4 \mathrm{a}$ & $1.9 \mathrm{~b}$ & $2.7 \mathrm{~b}$ & $3.8 \mathrm{a}$ & $\hat{y}=0.24 x^{2}-2.4 x+7.4$ & $92.0^{* *}$ \\
\hline RB 72454 & $9.0 \mathrm{a}$ & $7.0 \mathrm{a}$ & $4.3 \mathrm{a}$ & $5.4 \mathrm{a}$ & $5.2 \mathrm{a}$ & $5.7 \mathrm{a}$ & $\hat{y}=0.16 x^{2}-1.6 x+8.4$ & $72.7 * *$ \\
\hline RB 867515 & $8.1 \mathrm{a}$ & $4.7 \mathrm{a}$ & $3.4 \mathrm{a}$ & $5.2 \mathrm{a}$ & $5.3 \mathrm{a}$ & $4.4 \mathrm{a}$ & $\hat{y}=\bar{y}$ & -- \\
\hline Q 124 & $4.0 \mathrm{~b}$ & $5.7 \mathrm{a}$ & $4.6 \mathrm{a}$ & $3.2 \mathrm{~b}$ & $4.5 \mathrm{a}$ & $2.1 \mathrm{a}$ & $\hat{y}=-2.6 x+5.0$ & $43.3^{*}$ \\
\hline RB 961003 & $9.4 \mathrm{a}$ & $5.7 \mathrm{a}$ & $6.6 \mathrm{a}$ & $4.7 \mathrm{a}$ & $4.4 \mathrm{a}$ & $4.6 \mathrm{a}$ & $\hat{y}=0.12 x^{2}-1.5 x+8.6$ & $81.5^{*}$ \\
\hline RB 957508 & $5.5 \mathrm{~b}$ & $4.3 \mathrm{a}$ & $2.9 \mathrm{a}$ & $3.6 \mathrm{~b}$ & $4.0 \mathrm{a}$ & $2.8 \mathrm{a}$ & $\hat{y}=\bar{y}$ & -- \\
\hline SP 791011 & $6.2 \mathrm{~b}$ & $4.8 \mathrm{a}$ & $5.0 \mathrm{a}$ & $3.9 \mathrm{~b}$ & $1.7 \mathrm{~b}$ & $2.6 \mathrm{a}$ & $\hat{y}=-0.49 x+5.8$ & $83.2 * *$ \\
\hline RB 835089 & $7.9 \mathrm{a}$ & $6.1 \mathrm{a}$ & $5.2 \mathrm{a}$ & $4.9 \mathrm{a}$ & $6.5 \mathrm{a}$ & $4.3 \mathrm{a}$ & $\hat{y}=-0.26 x+6.8$ & $40.8^{*}$ \\
\hline RB 92579 & $10.0 \mathrm{a}$ & $6.3 \mathrm{a}$ & $4.6 \mathrm{a}$ & $6.1 \mathrm{a}$ & $4.0 \mathrm{a}$ & $3.7 \mathrm{a}$ & $\hat{y}=0.11 x^{2}-1.5 x+8.7$ & $71.2 *$ \\
\hline SP 943206 & $6.5 \mathrm{~b}$ & $6.5 \mathrm{a}$ & $3.9 \mathrm{a}$ & $3.0 \mathrm{~b}$ & $2.8 \mathrm{~b}$ & $3.7 \mathrm{a}$ & $\hat{y}=0.14 x^{2}-1.5 x+6.9$ & $89.8^{*}$ \\
\hline
\end{tabular}

Means followed by the same letter in the column are not different by the Scott Knott test at $5 \%$ probability. ${ }^{*}$ and ${ }^{* *}=$ significant regression at $5 \%$ and $1 \%$ probability, respectively.

The biochemical responses (total soluble and reducing sugar contents) of leaf tissues of the sugarcane plants as a function of increasing salinity levels in the irrigation water are shown in Tables 6 and 7. The total soluble sugar content of the varieties RB 72454 and RB 835089 presented a linear negative response to increasing salinity levels (Table $6)$.

Increase in the content of total soluble sugars (TSS) in the leaf tissue occurs when the drain force decreases (PAUL; PELLNY, 2003; AINSWORTH; BUSH, 2011), i.e., when their transport via phloem is compromised by the high salinity. This was showed by Lobo et al. (2011), who evaluated sorghum plants under salt stress and found that the higher total soluble carbohydrate accumulation in plants treated with $\mathrm{NaCl}$ could be due a low level of this solute or this accumulation was used for cell osmotic adjustment.

According to McCormick, Cramer and Watt (2008), photosynthesis in sugarcane plants is inhibited by the increase in hexose concentrations in leaves. This effect can explain the linear decrease in photosynthetic rate (Table 3) in the varieties Q 124 and SP 791011. However, the other varieties presented a quadratic response with the increasing of salt concentrations, indicating a decrease in photosynthetic rate up to a certain concentration due to a possible adjustment to the stress and, consequently, a recovery in photosynthetic activity.

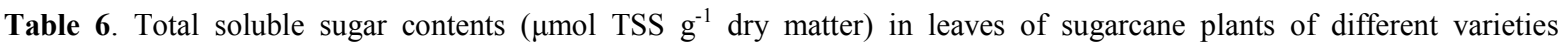
subjected to different salinity levels.

\begin{tabular}{|c|c|c|c|c|c|c|c|c|}
\hline \multirow[b]{2}{*}{ Variety } & \multicolumn{6}{|c|}{$\mathrm{EC}_{\mathrm{W}}\left(\mathrm{dS} \mathrm{m} \mathrm{m}^{-1}\right)$} & \multirow{2}{*}{$\begin{array}{l}\text { Regression } \\
\text { equation }\end{array}$} & \multirow{2}{*}{$\mathrm{R}^{2}$} \\
\hline & 0.0 & 1.0 & 2.0 & 4.0 & 6.0 & 8.0 & & \\
\hline VAT 90212 & $346.8 \mathrm{c}$ & $441.4 \mathrm{a}$ & $389.6 \mathrm{~b}$ & $419.9 \mathrm{~b}$ & $439.9 \mathrm{a}$ & $478.2 \mathrm{a}$ & $\hat{y}=\bar{y}$ & --- \\
\hline RB 72454 & $502.7 \mathrm{~b}$ & $298.5 \mathrm{a}$ & $427.9 \mathrm{~b}$ & $427.9 \mathrm{~b}$ & $243.6 \mathrm{~b}$ & $308.8 \mathrm{~b}$ & $\hat{y}=-22.0 x+447.7$ & $44.8^{* *}$ \\
\hline RB 867515 & $389.3 \mathrm{c}$ & $265.8 \mathrm{~b}$ & $444.7 \mathrm{a}$ & $500.7 \mathrm{a}$ & $384.6 \mathrm{a}$ & $340.9 \mathrm{~b}$ & $\hat{y}=-7.12 x^{2}+57.7 x+329.4$ & $34.7 * *$ \\
\hline Q 124 & $349.1 \mathrm{c}$ & $327.5 \mathrm{~b}$ & $469.9 \mathrm{a}$ & $393.6 \mathrm{~b}$ & $499.0 \mathrm{a}$ & $308.5 \mathrm{~b}$ & $\hat{y}=-8.12 x^{2}-66.3 x+322.8$ & $49.0 * *$ \\
\hline RB 961003 & $267.2 \mathrm{~d}$ & $381.2 \mathrm{a}$ & $407.8 \mathrm{a}$ & $313.6 \mathrm{~b}$ & $332.8 \mathrm{~b}$ & $439.4 \mathrm{a}$ & $\hat{y}=\bar{y}$ & --- \\
\hline RB 957508 & $335.9 \mathrm{c}$ & $401.1 \mathrm{a}$ & $349.6 \mathrm{~b}$ & $467.9 \mathrm{a}$ & $289.7 \mathrm{~b}$ & $227.0 \mathrm{~b}$ & $\hat{y}=-7.9 x^{2}-47.7 x+337.9$ & $71.0^{* *}$ \\
\hline SP 791011 & $385.3 \mathrm{c}$ & $219.1 \mathrm{~b}$ & $430.4 \mathrm{a}$ & $578.0 \mathrm{a}$ & $376.6 \mathrm{a}$ & $383.6 \mathrm{a}$ & $\hat{y}=-8.3 x^{2}-74.4 x+301.7$ & $28.6^{* *}$ \\
\hline RB 835089 & $559.0 \mathrm{a}$ & $419.1 \mathrm{a}$ & 546.2 a & $517.0 \mathrm{a}$ & $310.5 \mathrm{~b}$ & $358.7 \mathrm{~b}$ & $\hat{y}=-24.7 x+538.3$ & $53.4 * *$ \\
\hline RB 92579 & $220.0 \mathrm{~d}$ & $391.6 \mathrm{a}$ & $443.3 \mathrm{a}$ & $389.5 \mathrm{~b}$ & $405.1 \mathrm{a}$ & 495.7 a & $\hat{y}=21.6 x+315.4$ & $51.2^{* *}$ \\
\hline SP 943206 & $332.7 \mathrm{~b}$ & $240.2 \mathrm{~b}$ & $330.8 \mathrm{~b}$ & $482.4 \mathrm{a}$ & $414.6 \mathrm{a}$ & $264.4 \mathrm{~b}$ & $\hat{y}=-9.6 x^{2}+80.6 x+255.5$ & $52.0^{* *}$ \\
\hline
\end{tabular}

Means followed by the same letter in the column are not different by the Scott Knott test at $5 \%$ probability. $*$ and $* *=$ significant regression at $5 \%$ and $1 \%$ probability, respectively. 
W. L. SIMÕES et al.

Table 7. Total reducing sugar contents ( $\mu \mathrm{mol}$ TRS $\mathrm{g}^{-1}$ dry matter) in leaves of sugarcane plants of different varieties subjected to different salinity levels.

\begin{tabular}{|c|c|c|c|c|c|c|c|c|}
\hline \multirow[b]{2}{*}{ Variety } & \multicolumn{6}{|c|}{$\mathrm{EC}_{\mathrm{W}}\left(\mathrm{dS} \mathrm{m} \mathrm{m}^{-1}\right)$} & \multirow{2}{*}{$\begin{array}{c}\text { Regression } \\
\text { equation }\end{array}$} & \multirow{2}{*}{$\mathrm{R}^{2}$} \\
\hline & 0.0 & 1.0 & 2.0 & 4.0 & 6.0 & 8.0 & & \\
\hline VAT 90212 & $115.8 \mathrm{c}$ & $124.1 \mathrm{~d}$ & $156.2 \mathrm{~d}$ & $119.1 \mathrm{~d}$ & $228.7 \mathrm{~b}$ & $215.6 \mathrm{~b}$ & $\hat{y}=13.7 x+111.9$ & $70.1 * *$ \\
\hline RB 72454 & $139.5 \mathrm{c}$ & $150.1 \mathrm{~d}$ & $227.5 \mathrm{~b}$ & $202.0 \mathrm{c}$ & $198.4 \mathrm{c}$ & $278.5 \mathrm{a}$ & $\hat{y}=13.6 x+151.8$ & $67.1 * *$ \\
\hline RB 867515 & $353.6 \mathrm{a}$ & $264.7 \mathrm{~b}$ & $299.3 \mathrm{a}$ & $276.9 \mathrm{~b}$ & $247.3 \mathrm{~b}$ & $156.5 \mathrm{c}$ & $\hat{y}=-18.7 x+331.8$ & $78.0^{* *}$ \\
\hline Q 124 & $229.1 \mathrm{~b}$ & $163.8 \mathrm{c}$ & $228.8 \mathrm{~b}$ & $240.2 \mathrm{~b}$ & $362.4 \mathrm{a}$ & $305.1 \mathrm{a}$ & $\hat{y}=17.8 x+192.7$ & $62.7 * *$ \\
\hline RB 961003 & $345.8 \mathrm{a}$ & $145.7 \mathrm{~d}$ & $216.5 \mathrm{~b}$ & $174.5 \mathrm{c}$ & $192.8 \mathrm{c}$ & $180.9 \mathrm{c}$ & $\hat{y}=4.85 x^{2}-49.4 x+284.5$ & $43.5^{* *}$ \\
\hline RB 957508 & $109.4 \mathrm{c}$ & $192.9 \mathrm{c}$ & $144.7 \mathrm{~d}$ & $216.6 \mathrm{c}$ & $168.9 \mathrm{~d}$ & $228.1 \mathrm{~b}$ & $\hat{y}=10.0 x+141.8$ & $46.9 * *$ \\
\hline SP 791011 & $214.6 \mathrm{~b}$ & $107.1 \mathrm{~d}$ & $263.7 \mathrm{a}$ & $257.8 \mathrm{~b}$ & $157.7 \mathrm{~d}$ & $183.2 \mathrm{c}$ & $\hat{y}=-2.9 x^{2}+21.9 x+179.8$ & $11.1^{* *}$ \\
\hline RB 835089 & $180.1 \mathrm{~b}$ & $183.1 \mathrm{c}$ & $221.5 \mathrm{~b}$ & $220.1 \mathrm{c}$ & $149.9 \mathrm{~d}$ & $147.1 \mathrm{c}$ & $\hat{y}=-5.8 x+203.8$ & $30.0 * *$ \\
\hline RB 92579 & $121.0 \mathrm{c}$ & $340.2 \mathrm{a}$ & $193.8 \mathrm{c}$ & $225.3 \mathrm{c}$ & $191.6 \mathrm{c}$ & $209.3 \mathrm{~b}$ & $\hat{y}=\bar{y}$ & --- \\
\hline SP 943206 & $137.8 \mathrm{c}$ & $141.4 \mathrm{~d}$ & $134.1 \mathrm{~d}$ & $319.2 \mathrm{a}$ & $136.9 \mathrm{~d}$ & $168.2 \mathrm{c}$ & $\hat{y}=-5.4 x^{2}+47.4 x+115.5$ & $28.5^{* *}$ \\
\hline
\end{tabular}

Means followed by the same letter in the column are not different by the Scott Knott test at $5 \%$ probability. ${ }^{*}$ and $* *=$ significant regression at $5 \%$ and $1 \%$ probability, respectively.

TSS consist basically of hexoses compounds (reducing) and other sugars of longer chains that have storage and transport functions, such as sucrose. Reducing sugars consist basically of glucose and a small portion of raffinose and mannose, which are used as energy and nutrient reserve by plants (TAIZ et al., 2017). According to Mesquita et al. (2015), TSS contents are greater than TRS contents, and the greater this difference, the higher the sucrose contents. Thus, the total availability of sugars with transport function to several drains of plants is affected by increases in electric conductivity.

\section{CONCLUSION}

The highest chlorophyll contents were found in sugarcane plants of the varieties Q 124, RB 96103, RB 835089, and SP 943206.

The salinity levels affected sugarcane plants of different varieties, causing variations in gas exchange, total soluble sugar contents, and total reducing sugar contents, promoting an adaptability of the plants to the salt stress conditions.

The decreases in stomatal conductance resulted in decreases in photosynthetic rates in plants of all sugarcane varieties evaluated, except for RB 867515 .

\section{REFERENCES}

AINSWORTH, E. A.; BUSH, D. R. Carbohydrate export from the leaf: a highly regulated process and target to enhance photosynthesis and productivity. Plant Physiology, v. 155, n. 1, p. 64-69, 2011.
BARROS, T. H. S. et al. Influence of Sugarcane Genotype and Soil Moisture Level on the Arbuscular Mycorrhizal Fungi Community. Sugar Tech, v. 20, n. 3, p. 1-9, 2018.

BROSCHÉ, M. et al. Stress signaling III: Reactive Oxygen Species (ROS). In: PAREEK, A.; SOPORY, S. K.; BOHNERT, H. J.; GOVINDJEE, G. (Eds.). Abiotic stress adaptation in plants: pysiological, molecular and genomic foundation. Dordrecht: Springer, 2010. p. 91-102.

COMPANHIA BRASILEIRA DE ABASTECIMENTO - CONAB. Acompanhamento da safra brasileira: cana-de-açúcar, safra 2018/19. Terceiro levantamento, Brasília, v. 5, n. 3, p. 1-71, Brasília, DF, 2019. Disponível em: <https:// www.conab.gov.br/info-agro/safras/cana/boletim-dasafra-de-cana-de-acucar>. Acesso em: 6 jan. 2019.

CORREIA, K. G. et al. Crescimento, produção e características de fluorescência da clorofila a em amendoim sob condições de salinidade. Revista Ciência Agronômica, v. 40, n. 4, p. 514-521, 2009.

DIAS, N. S.; BLANCO, F. F. Efeitos dos sais no solo e na planta. In: GHEYI, H. R.; DIAS, N. S.; LACERDA, C. F (Eds.). Manejo da salinidade na agricultura: Estudos básicos e aplicados. Fortaleza: INCT Sal, 2010, v.1, cap. 9, p. 129 - 141.

INMAN-BAMBER, N. G.; SMITH, D. M. Water relations in sugarcane and response to water deficits. Field Crops Research, v. 92, n. 2-3, p. 185-202, 2005. 
JAMIL, M. et al. Salinity reduced growth PS2 photochemistry and chlorophyll content in radish. Scientia Agricola, v. 64, n. 2, p. 111-118, 2007.

LEAL, D. P. V. et al. Water productivity for sugar and biomass of sugarcane varieties. Revista Brasileira de Engenharia Agrícola e Ambiental, v. 21, n. 9, p. 618-622, 2017.

LOBO, A. K. M. et al. Compostos nitrogenados e carboidratos em sorgo submetido à salinidade e combinações de nitrato e amônio. Revista Ciência Agronômica, v. 42, n. 2, p. 390-397, 2011.

McCORMICK, A.J.; CRAMER, M.D.; WATT, D.A. Changes in photosynthesis rates and gene expression of leaves during a source-sink perturbation in sugarcane. Annals of Botany, v. 101, n. 9, p. 89102, 2008.

MESQUITA, A. C. et al. Efeito da aplicação de fontes de nitrogênio em plantas de umbuzeiro propagadas via sexuada e assexuada. Revista SODEBRAS, v. 10. n. 114, p., 2015.

PACHECO, C. M. et al. Differentially Delayed Root Proteome Responses to Salt Stress in Sugar Cane Varieties. Journal of Proteome Research, v. 12, n. 12 , p. 13 - 19, 2013.

PAUL, M. J.; PELLNY, T. K. Carbon metabolite feedback regulation of leaf photosynthesis and development. Journal of Experimental Botany, v. 54, n. 382, p. 539-547, 2003.

REDDY, S. J.; AMORIM NETO, M. S. Dados de precipitação, evapotranspiração potencial, radiação solar global de alguns locais e classificação climática do Nordeste do Brasil. Petrolina: Embrapa Semiárido, 1983. 280p.

SIMÕES, W. L. et al. Growth of sugar cane varieties under salinity. Revista Ceres, v. 63, n. 2, p. 265271, 2016.

SIMÕES, W. L. et al. Respostas de variáveis fisiológicas e tecnológicas da cana-de-açúcar a diferentes sistemas de irrigação. Revista Ciência Agronômica, v. 46, n. 1, p. 11-20, 2015.

SIMÕES, W. L. et al. Sugarcane crops with controlled water deficit in the Sub-Middle São Francisco Valley, Brazil. Revista Caatinga, v. 31, n. 4, p. 963-971, 2018.

TAIZ, L. et al. Fisiologia e desenvolvimento vegetal. 6. ed. Porto Alegre, RS: Artmed, 2017. 858 p.
TEIXEIRA, P. C. et al. Manual de métodos de análise de solo. 3.ed. Brasília, DF: Embrapa Solos, 2017. 573 p.

WILLADINO, L. et al. Estresse salino em duas variedades de cana-de-açúcar: enzimas do sistema antioxidativo e fluorescência da clorofila. Revista Ciência Agronômica, v. 42, n. 2, p. 417-422, 2011. 